\title{
Evaluation of PM Emissions of a Diesel Engine Fueled with Waste Cooking Oil Biodiesel: A Systematic Review
}

\author{
Omobolanle H. Oshinusi ${ }^{1 *}$ and George M. Gray ${ }^{1}$ \\ ${ }^{1}$ The George Washington University, USA
}

\begin{abstract}
The Navigation Guide developed by Johnson et al was used to conduct a robust systematic review of six experimental intervention studies comparing particulate matter (PM) emissions from heavy-duty diesel engines using waste cooking oil biodiesel versus conventional petroleum diesel fuel. Waste cooking oil biodiesel is thought to be a more sustainably sourced alternative to its fossil fuel counterpart and can aid in reducing cooking oil waste streams. The Navigation Guide systematic review methodology tool was applied to analyse the hypothesized question: Does the replacement of petroleum diesel with waste cooking oil biodiesel reduce hazardous PM emissions in heavy duty vehicles? The study question was specified, evidence was selected and the quality and strength of the overall evidence was assessed for both individual studies and across the body of studies. Precise criteria and protocols were developed and followed throughout the review process to ensure that a thorough evaluation of all data was completed. All six studies that met the review inclusion criteria utilized six-cylinder direct injection engines. Although the PM emissions were measured differently across the exposure continuum, there was an overall PM emission reduction of $28 \%$ across the studies when petroleum diesel was substituted with waste cooking oil biodiesel. The overall risk of bias across the studies was determined to be 'low'. Based on the application of the Navigation guide methodology, it was found that the strength of the evidence provided was 'sufficient' to suggest an association between waste cooking oil biodiesel and PM emission reductions.
\end{abstract}

Keywords: Waste cooking oil, Biodiesel, Particulate matter, Sustainability

\section{Introduction}

For decades, the vast increase in the human population coupled with the combustion and use of non-renewable energy sources has led to an ongoing discussion on the relationship between outdoor air pollutants and its associated environmental and health effects. Air pollution, defined as the presence of air pollutants in large enough quantities that may prove harmful to human, animal or plant life, has been researched extensively.

In particular, there are growing global concerns regarding the depletion of natural crude oil and the increased greenhouse gas emissions associated with high petroleum usage. Petroleum oil accounts for approximately $40 \%$ of the total energy usage in the United States (U.S. EIA 2016). Of that, the transportation sector utilizes motor gasoline at increasing levels, with 8964 thousand barrels used per day in 2016 (U.S. EIA 2017). Diesel is a substituent formed from petroleum crude oil, and has become a popular transportation fuel alternative to gasoline, constituting $21 \%$ of petroleum consumed in the U.S. transportation sector (U.S. EIA 2017). It's typically used in trucks, trains and heavy-duty off-road automotive vehicles due to its lighter weight and greater energy density per unit of volume.

Despite its energy benefits, diesel is still a major contributor of carbon dioxide, the most prevalent greenhouse gas. Approximately 22 pounds of $\mathrm{CO}_{2}$ is produced for every gallon of diesel fuel that is burned, compared to about 19 pounds of $\mathrm{CO}_{2}$ per gallon of gasoline. (U.S. EIA 2017). Advances in technology have allowed for the development of more sustainably-sourced diesel fuel-blend (biodiesel) alternatives. Research has shown that combustion of B20, a common biodiesel fuel composed of $20 \%$ soybean oil and $80 \%$ petroleum diesel, has 
shown promising results in emissions of 17 pounds of $\mathrm{CO}_{2}$ per gallon (U.S. EIA 2017). Using waste cooking oil (WCO) as a petroleum diesel blend has become an attractive sustainable solution. It can be locally sourced more easily and contribute to a large reduction in waste production. Hotels and restaurants in the U.S. alone are estimated to generate up to 3 billion gallons of WCO each year (U.S. EIA 2016), demonstrating a large potential for WCO collection from other sectors.

Although benefits in carbon dioxide reduction have already been established, there are still some uncertainties as to whether there are similar trends shown for particulate matter (PM) emissions. A subcategory of particulate matters, $\mathrm{PM}_{2.5}$, is a prevalent air pollutant made up of a variety of particulates with a size of $2.5 \mu \mathrm{m}$ or smaller. These particulates raise public health concerns because of their ability to penetrate deeply into the respiratory tract, and have been studied extensively to determine potential adverse health impacts. Identified health issues that have been linked to PM2.5 exposure include coughing, shortness and tightness of breath, reduced lung function and aggravation of existing lung and/or heart conditions (U.S. EPA 2012).

PM emissions from petroleum diesel engines vary based on the type of engine used, but are approximately six to ten times higher than standard gasoline engines (Reşitoğlu et.al 2014), and have shown to contribute 10-36\% of total PM emissions in some densely populated urban areas (U.S. EPA 2002). This paper is a detailed systematic review that assesses the overall quality of evidence from relevant studies that comprehensively looked at PM emissions in heavy-duty compression ignition engines tested with petroleum diesel versus a $20 \%$ WCObiodiesel blend. Conclusions will be drawn by evaluating whether a WCO- biodiesel alternative is associated with reduced PM emissions and how this could aid to combat adverse environmental, health and waste impacts seen today.

\section{Methods}

\section{Systematic Review Methodology}

This systematic review was conducted in conjunction with an environmental health sciences review methodology tool called the Navigation Guide (Johnson et.al 2014). The use of this guide required that each of the selected studies were assessed and rated based on the investigations of the association between PM emissions and the use of petroleum diesel versus WCO-biodiesel. The risk of bias, strength of evidence and overall study quality were evaluated and are presented in the results section.

\section{Study Question}

The objective of this systematic review is based on the hypothesis that PM tailpipe emissions are affected by switching from petroleum diesel to a WCO-biodiesel alternative. Each element of the study question is outlined and developed from the PICO statement below.

Population - Heavy-duty automotive diesel engines

Intervention - Waste Cooking Oil Biodiesel: Experimental intervention studies were selected that used a WCObiodiesel blend in replacement of standard petroleum diesel in heavy-duty compression ignition engines under similar experimental conditions.

Comparator - Petroleum Diesel

Outcome - PM emission levels: A quantitative analysis including the percentage of PM emitted was recorded in each study. 


\section{Data Sources}

A thorough and extensive search strategy was conducted by using the PICO statement as a guide to coin a series of search terms and synonyms which addressed the specified intervention and outcome of interest. Minute changes were then made in the search terms to aid in widening the range of results found. The search primarily utilized the electronic databases ScienceDirect, and Scopus, between the 20th September and 3rd October 2017. Additional terms were coined and searched between the 10th and 13th of October 2017. Other sources used included academic literature, such as the George Washington University Library, and internet databases. The citations and bibliographies of titles and abstracts that were screened for further review were checked for additional potential studies. The search was limited to studies written in English and that were published after 2010.

\section{Study Selection}

Studies were selected in which a primary experimental intervention was conducted to test and compare the PM emissions from heavy-duty compression ignition automotive engines using standard petroleum diesel versus a $20 \%$ WCO-biodiesel blend. A general screening of titles was conducted and then once studies were selected, a further screening of abstracts was completed to determine if the subject matter of the article was appropriate for further intensive review. The online citation tool, RefWorks, was used to remove duplicates and organize the chosen studies throughout the screening process. Only studies that were published from 2010 onwards were reviewed, due to the development and improvement of technology used to produce these biodiesels. The list below outlines the eligibility criteria used to screen studies.

Studies were excluded if:

- They did not contain their own original data or observations.

- They failed to mention the blend ratio of the waste cooking oil biodiesel (20\%) and the observance of PM in the title/abstract.

- The biodiesel and petroleum diesel comparisons were not carried out on heavy-duty compression ignition automotive engines.

- They were not experimental intervention studies (i.e. engines were not tested under the same circumstances)

- They were conducted prior to 2010 .

- They were not written in English.

\section{Assessing the Risk of Bias for Each Included Study}

Each of the final individual papers selected for the systematic review were evaluated to determine if and what risk of bias may have occurred during the completion of the study. As outlined in the Navigation Guide, the different bias domains considered included: recruitment strategy, blinding, confounding, exposure assessment, selective outcome reporting and possible conflicts of interest (Johnson et.al 2014). Each bias domain has their own specific assessment criteria and was appointed a rating on a scale of "low risk", "probably low risk", "probably high risk", "high risk" and "not applicable" (Johnson et.al, 2014), with accompanying support as to why these judgements were made. Once the individual study assessments were made, the risks were then evaluated based on the entire body of studies using the same criteria, to aid in ensuring consistent interpretation.

The recruitment strategy was assessed to determine whether the procedures used in the experimental testing of the studies were applied consistently amongst the entire study population. Whether blinding was used showed 
that the PM emission outcome was fairly presented without any prior knowledge of the type of fuel used by the investigator.

The exposure assessment was evaluated to discern if appropriate measures were taken to avoid exposure misclassification and if the testing procedures and methods containing WCO-biodiesel and petroleum diesel had been done in the same fashion across the study. Identification of any alterations to the engines were also evaluated within this risk domain.

Potential confounding variables should have been acknowledged and controlled for appropriately throughout the course of the experiments. The final investigative studies chosen for this review were conducted under the most similar circumstances to aid in controlling for these factors. All the outcomes measured should have been presented, regardless if they met the hypothesized result or not, to reduce the risk of selective outcome reporting and increase the robustness of the obtained results. Finally, the acknowledgement sections were assessed to determine if any conflict of interests occurred. This may have been in the form of any outstanding financial support from private organizations or other entities that would obscure the overall results of the study.

\section{Rating the Quality and Strength of the Evidence across Studies}

A rating scale ranging from 'high' to 'moderate' to 'low' was developed to methodically assess the overall quality of the body of evidence presented across the studies. Due to the nature of these experimental investigative studies and the lack of human participants, the 'Grading and Recommendations Assessment Development and Evaluation' System (GRADE) (Balshem et.al 2011) typically used in conjunction with the Navigation Guide, could not be directly utilized. Therefore, all the studies were assigned an initial 'high' rating, and downgraded based on whether any of the evaluated risk of bias domains were categorized as 'probably high risk' or 'high risk'.

Rating the strength of the body of evidence aided in determining if there was enough indication to decide whether the hypothesized intervention can lead to decided action. In conjunction with the quality of evidence rating mentioned above, the direction of the effect estimate and identification of other compelling attributes of the data that might influence uncertainty (Johnson et.al 2014) contributed towards the rating for the overall strength of evidence. The rating scale assignments are 'sufficient evidence of reduced PM emissions', 'limited evidence of reduced PM emissions', 'inadequate evidence of reduced PM emissions' or 'evidence of no reduction in PM emissions'.

\section{Results}

\section{Included Studies}

Out of 2295 uniquely screened studies, a total of six were selected for final comparative analysis. Figure 1 is a flowchart that demonstrates the literature search and the breakdown of the number of studies selected during each screening process. In addition to the exclusion criteria outlined in the methods, additional reasons for excluding studies during the title/abstract and final study screenings included:

- They were not an experimental intervention study design

- The use of bioethanol instead of petroleum biodiesel as a comparator

- The use of diesel generator engines instead of heavy-duty automotive engines

- Studies that only conducted life cycle assessments of biodiesel

- Studies using a different blend ratio of biodiesel other than $20 \%$ 
- The conducted emissions tests did not include particulate matter (PM) in the final analysis

The characteristics of each study are outlined in Table 1 below. All were experimental interventions studies that were conducted between 2010 and 2017, allowing for the implementation of newer technologies for biodiesel development.

\section{Risk of Bias Assessment for Individual Studies}

The Hadavi et al study (Hadavi et.al 2015) was one of three studies (including Kawana et.al and Martin et.al) to test the use of WCO-biodiesel under real world conditions. PM emissions were tested using a refined straight used cooking oil (named C2G Ultra Biofuel) on 10 heavy-duty commercial trucks provided by United Biscuits Ltd, a large multinational food manufacturing company. Selecting vehicles from the same fleet increased the likelihood of comparative results (i.e. low risk for recruitment bias), however, the involvement of this large

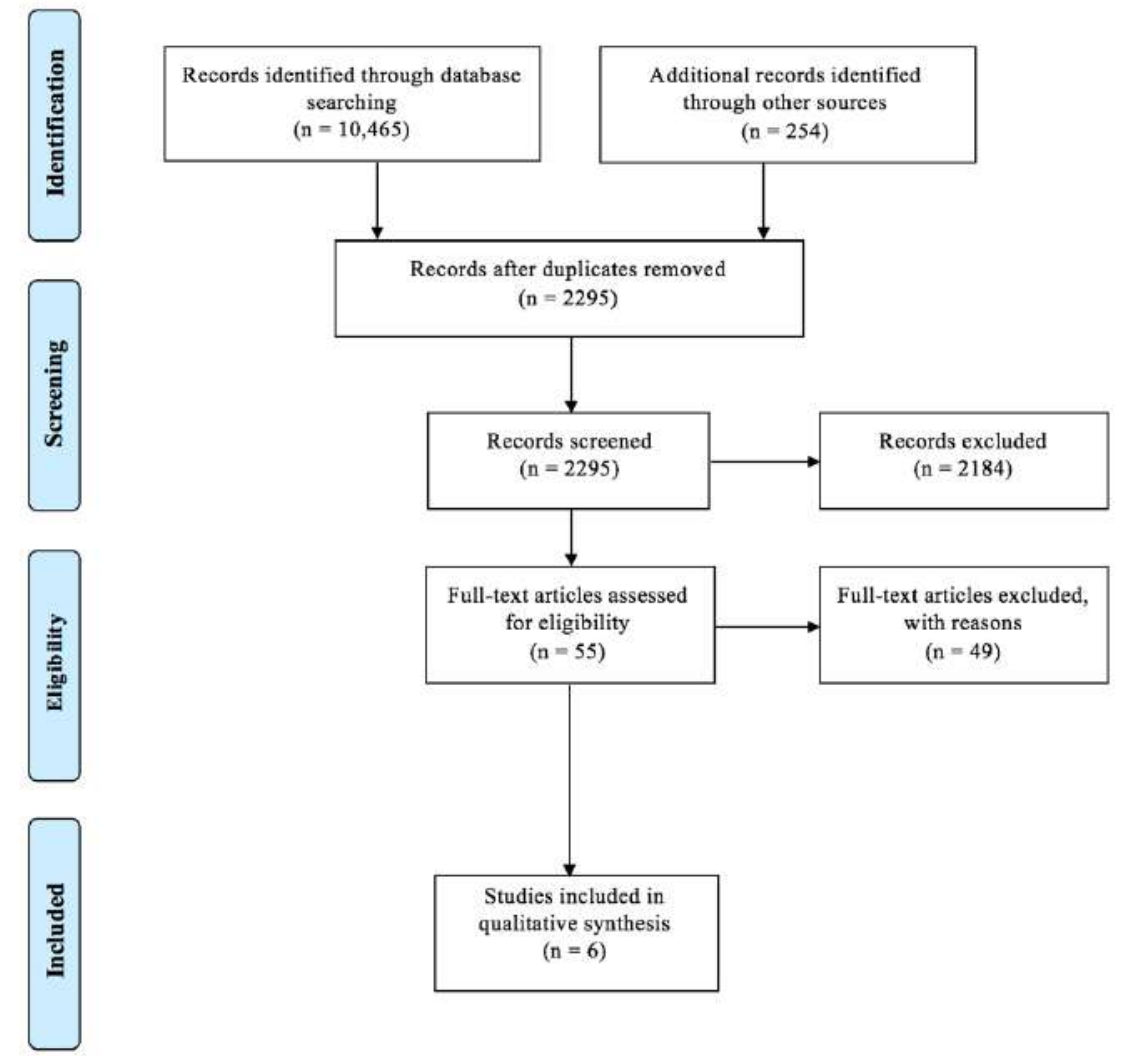

Figure 1. Flowchart demonstrating breakdown of literature search and screening process.

private organization resulted in the 'probably high risk' rating for the conflict of interest domain. Upon further review, it was determined that this private funding was not shown to affect the quality of the study's results. The engines were converted to be able to burn both the $\mathrm{C} 2 \mathrm{G}$ Ultra Biofuel and standard petroleum diesel before testing begun. PM exhaust samples were taken using Anderson impactors in the tailpipe. Although alterations were made, they were consistent amongst all the engines, ensuing the 'probably low risk' determination for the exposure assessment. Additionally, all vehicles were tested when loaded versus empty, were driven by the same driver, and were driven along the same route, to ensure consistency among testing procedures. Confounding variables were not acknowledged, but using the same drivers and routes decreased their likelihood. Also, selective outcome reporting was not shown in this study. Overall, PM emissions decreased by $69.5 \%$ when 
looking at the average concentration between petroleum diesel $\left(1.77 \mathrm{mg} / \mathrm{m}^{3}\right)$ and C2G Ultra Biofuel $\left(0.53 \mathrm{mg} / \mathrm{m}^{3}\right)$. The overall risk of bias for this study was concluded to be 'probably low risk'.

The aim of the Kawano et al study was to determine if the use of WCO-biodiesel would comply with national short-term and long-term regulations for exhaust emissions, potentially strengthening the argument for the biodiesel's implementation and feasibility (Kawano et.al 2010). An older heavy-duty diesel bus was used to test compliance with short-term regulations, and two newer heavy-duty diesel busses tested compliance with longterm regulations. Blinding was not utilized in this study; however, it may have been effective as these researchers are already accustomed to the use of WCO-biodiesel and may be expecting positive results. These buses were already equipped to work with WCO-biodiesel, making the recruitment strategy low risk. In Kyoto, Japan (where the study was conducted), there is already a WCO collection scheme and large biodiesel production plant in place. The tests were conducted according to Japanese regulation by using a chassis dynamometer for transient emission characteristics. No measurement alterations were made to the engines, and PM was collected on a Teflon filter downstream of the exhaust pipes. No selective outcome reporting was observed. There was an average PM reduction of approximately $19 \%$ with the use of biodiesel when averaged between the older and newer vehicles. The overall risk of bias was found to be 'low risk' for this study.

The entirety of this Lin et al study (Lin et.al 2010) was conducted in close resemblance to the Liu et al study described below, excluding the use of a catalyzer. The test engine provided is one that is commonly used to conduct emissions tests for national pollutant emission regulations. Testing conditions were made to resemble urban and freeway driving conditions, although it was not necessarily conducted in a real-world setting. The use of blinding was not acknowledged, although it does not appear to have affected study outcomes. A monitoring system were used to facilitate continuous measurements of PM emissions, but no alterations were made to the engine itself, demonstrating low risk of bias for exposure assessment. Selective outcome reporting was not shown in this study. The conflict of interest domain was found to be 'probably low risk', as most of the financial support was provided from a grant by the National Science Council of Taiwan, but the engine was provided by CPC Corporation, a publicly owned petroleum, natural gas and gasoline company. There was a PM reduction of approximately $7.4 \%$ when fueled with WCO-biodiesel $\left(0.212 \mathrm{~g} \mathrm{BHP}^{-1} \mathrm{~h}^{-1}\right)$ compared to petroleum diesel $(0.229$ $\left.\mathrm{g} \mathrm{BHP}^{-1} \mathrm{~h}^{-1}\right)$. The overall risk of bias was 'low risk' for this study.

The Liu et al study utilized a heavy-duty diesel engine equipped with a catalyzer under conditions to mimic typical urban and freeway driving conditions. There was no mention of how the engine was obtained, or chosen for this particular study. Therefore, recruitment strategy was deemed 'probably low risk'. The use of blinding was not acknowledged, although it does not appear to have affected study outcomes. A similar dilution and monitoring system were utilized to collect PM emissions, with no alterations made. PM emissions were collected using glass-fiber filters. Confounding variables were not acknowledged, but are assumed to not have affected results shown. Also, selective outcome reporting was not shown in this study. No financial conflicts of interest were identified with this study, as the only support provided was through a grant from the National Science Council of Taiwan. PM emissions were shown to decrease by $15.5 \%$ when fueled with WCO-biodiesel $\left(0.087 \mathrm{~g} \mathrm{BHP}^{-1} \mathrm{~h}^{-1}\right)$ compared to petroleum diesel $\left(0.103 \mathrm{~g} \mathrm{BHP}^{-1} \mathrm{~h}^{-1}\right)$. The overall risk of bias was 'low risk' for this study.

The aim of the Martin et al study was to "perform an exposure assessment on an active worksite to better approximate PM inhalation levels" (Martin et al 2016). One heavy-duty 6-cylinder non-road vehicle was first fueled with petroleum diesel and then a $20 \%$ waste grease (WG) biodiesel blend. Smoking was identified and eliminated as a confounding factor due to the testing taking place in a smoke-free worksite. The recruitment strategy was considered to be low risk for this study, as the day-to-day operations were not interfered with, therefore not effecting the PM emissions shown. The use of blinding was not mentioned by researchers, and was classified as probably low risk. PM emissions were collected using pumped cascade impactors on the vehicles and in the areas of the site that were estimated to have the most worker activity. No alterations were made to the 
test vehicles' engines before the use of petroleum diesel and WG-biodiesel, therefore the exposure assessment was also found to be low risk. Selective outcome reporting was not present and was deemed as low risk.

Additionally, no conflict of bias appeared to be present, although no official statements were declared. This resulted in a rating of 'probably low risk'. The PM emitted when the engine used WG-biodiesel was $53 \mu \mathrm{g} / \mathrm{m}^{3}$, an $8.6 \%$ reduction from the $58 \mu \mathrm{g} / \mathrm{m}^{3}$ seen from use of petroleum diesel. Overall, this study was determined to have an overall low risk of bias.

Finally, the Nabi et al study evaluated engine performance and emission patterns with WCO-biodiesel on a 6cylinder heavy-duty common rail diesel engine. The reason for the researchers using this engine was not identified, resulting in the 'probably low risk' rating for recruitment strategy. The test procedure was conducted multiple times while the engine was set at different speeds and different loads, making for a robust exposure assessment. A dilution tunnel and aerosol monitor were used to gather PM emission measurements, but no alterations were made to the engine itself. There were no conflicting interests identified, as the study was funded under the Australian Research Council. On average, there was an approximately 47\% reduction in PM emissions across all loads and speeds when compared to the petroleum diesel results. The overall risk of bias for this study was deemed to be 'low'.

Figures $2 \mathrm{a}$ and $2 \mathrm{~b}$ provide a visualization of the risk of bias ratings for each of the studies and across the body of studies. All the studies carried out their tests on heavy-duty 6-cylinder direct injection diesel engines, and minimal, if any, adjustments were made to the engines themselves. The conflict of interest domain had the highest risk across the studies, due to the involvement of some private organizations, however no major concerns were raised that would obscure the accuracy of results shown. 
Omobolanle H. Oshinusi and George M. Gray/Evaluation of PM Emissions of a Diesel Engine....

Table 1 Summary of study characteristics evaluating PM emissions from use of WCO-biodiesel in heavy-duty diesel engines

\begin{tabular}{|c|c|c|c|c|c|c|}
\hline Source & Location of Study & Type of Engine & Type of Biodiesel & Outcome Measured & Test Procedure & Major Results \\
\hline $\begin{array}{l}\text { Hadavi et al, } \\
2015\end{array}$ & $\begin{array}{l}\text { Ashby, United } \\
\text { Kingdom }\end{array}$ & $\begin{array}{l}\text { Heavy-duty direct injection } \\
\text { compression ignition } \\
\text { turbocharged 6-cylinder diesel } \\
\text { engine }\end{array}$ & $\begin{array}{l}\text { C2G ultra biofuel made } \\
\text { with refined used } \\
\text { cooking oils, } 20 \% \\
\text { blend }\end{array}$ & $\begin{array}{l}\text { PM emissions collected with } \\
\text { Anderson Impactor and } \\
\text { preconditioned glass fiber filter } \\
\text { papers }\end{array}$ & $\begin{array}{l}\text { Tests completed on tractors with } \\
\text { empty and loaded trailers in real- } \\
\text { world setting }\end{array}$ & $\begin{array}{l}\text { 69.5\% reduction in PM } \\
\text { emissions from petroleum } \\
\text { diesel }\left(1.77 \mathrm{mg} / \mathrm{m}^{3}\right) \text { to } \mathrm{C} 2 \mathrm{G} \\
\text { ultra biofuel }\left(0.53 \mathrm{mg} / \mathrm{m}^{3}\right)\end{array}$ \\
\hline $\begin{array}{l}\text { Kawano et al, } \\
2010\end{array}$ & Kyoto, Japan & $\begin{array}{l}\text { Heavy-duty 6-cylinder 7.79L } \\
\text { direct injection turbo diesel } \\
\text { engine }\end{array}$ & $\begin{array}{l}\text { Waste cooking oil } \\
\text { biodiesel, } 20 \% \text { blend- } \\
\text { collected from } \\
\text { households, hotels and } \\
\text { restaurants and } \\
\text { converted to biodiesel }\end{array}$ & $\begin{array}{l}\text { PM collected on a Teflon filter } \\
\text { while at constant air flow }\end{array}$ & $\begin{array}{l}\text { Transient mode test cycle } \\
\text { conducted on chassis dynamometer } \\
\text { for investigation of transient } \\
\text { emission characteristics }\end{array}$ & $\begin{array}{l}\text { 19.2\% average reduction in } \\
\text { PM emissions from petroleum } \\
\text { diesel }(0.026 \mathrm{~g} / \mathrm{kWh}) \text { to WCO- } \\
\text { biodiesel }(0.021 \mathrm{~g} / \mathrm{kWh})\end{array}$ \\
\hline Lin et al. 2010 & Kaohsiung, Taiwan & $\begin{array}{l}\text { Heavy-duty Cummins BD.9- } \\
160 \text { turbocharged direct } \\
\text { injection 6-cylinder diesel } \\
\text { engine }\end{array}$ & $\begin{array}{l}\text { Waste cooking oil } \\
\text { biodiesel, } 20 \% \text { blend }\end{array}$ & $\begin{array}{l}\text { Dilution tunnel and monitoring } \\
\text { system installed downstream of } \\
\text { exhaust to facilitate continuous } \\
\text { measurement of suspended PM } \\
\text { particles }\end{array}$ & $\begin{array}{l}\text { Schenck GS-350 dynamometer } \\
\text { used to mimic typical driving } \\
\text { conditions }\end{array}$ & $\begin{array}{l}7.4 \% \text { reduction in } \mathrm{PM} \\
\text { emissions from petroleum } \\
\text { diesel }\left(0.229 \mathrm{~g} \mathrm{BHP}^{-1} \mathrm{~h}^{-1}\right) \text { to } \\
\text { WCO-biodiesel }(0.212 \mathrm{~g} \mathrm{BHP} \\
\left.{ }^{1} \mathrm{H}^{-1}\right)\end{array}$ \\
\hline Liu et al, 2012 & Kaohsiung, Taiwan & $\begin{array}{l}\text { Heavy-duty Cummins BD.9- } \\
160 \text { turbocharged direct } \\
\text { injection 6-cylinder diesel } \\
\text { engine }\end{array}$ & $\begin{array}{l}\text { Waste cooking oil } \\
\text { biodiesel, } 20 \% \text { blend }\end{array}$ & $\begin{array}{l}\text { Dilution tunnel and monitoring } \\
\text { system installed downstream of } \\
\text { exhaust to facilitate continuous } \\
\text { measurement of suspended PM } \\
\text { particles }\end{array}$ & $\begin{array}{l}\text { Mild engine loaded conditions to } \\
\text { represent typical urban and freeway } \\
\text { driving }\end{array}$ & $\begin{array}{l}\mathbf{1 5 . 5 \%} \text { reduction in } \mathrm{PM} \\
\text { emissions from petroleum } \\
\text { diesel }\left(0.103 \mathrm{~g} \mathrm{BHP}^{-1} \mathrm{H}^{-1}\right) \text { to } \\
\text { WCO-diesel }\left(0.087 \mathrm{~g} \mathrm{BHP}^{-1} \mathrm{~h}^{-}\right. \\
\left.{ }^{1}\right)\end{array}$ \\
\hline $\begin{array}{l}\text { Martin et al, } \\
2016\end{array}$ & $\begin{array}{l}\text { Keene, New } \\
\text { Hampshire USA }\end{array}$ & $\begin{array}{l}\text { Heavy-duty large front loader } \\
\text { 6-cylinder diesel engine }\end{array}$ & $\begin{array}{l}\text { Waste grease } \\
\text { biodiesel., } 20 \% \text { blend }\end{array}$ & $\begin{array}{l}\text { PM emissions collected using a } \\
\text { Sioutas cascade impactor }\end{array}$ & $\begin{array}{l}\text { Non-road equipment run on diesel } \\
\text { and biodiesel for } 16 \text { days and } \\
\text { impactors placed at different } \\
\text { locations to collect varying PM } \\
\text { exposure }\end{array}$ & $\begin{array}{l}\text { 8.6\% reduction in PM } \\
\text { emissions from petroleum } \\
\text { diesel }\left(58 \mu \mathrm{g} / \mathrm{m}^{3}\right) \text { to WG- } \\
\text { biodiesel }\left(53 \mu \mathrm{g} / \mathrm{m}^{3}\right)\end{array}$ \\
\hline $\begin{array}{l}\text { Nabi et al, } \\
2017\end{array}$ & Perth, Australia & $\begin{array}{l}\text { Heavy-duty 6-cylinder } \\
\text { common rail diesel engine }\end{array}$ & $\begin{array}{l}\text { Waste cooking oil } \\
\text { biodiesel, } 20 \% \text { blend }\end{array}$ & $\begin{array}{l}\text { PM was collected using a } \\
\text { DustTrak II Aerosol Monitor } \\
8530\end{array}$ & $\begin{array}{l}\text { Engine operated in } 14 \text {-mode } \\
\text { European Stationary Cycle to } \\
\text { observe emissions with different } \\
\text { biodiesel blends }\end{array}$ & $\begin{array}{l}\mathbf{4 7 \%} \text { average PM reduction } \\
\text { from petroleum diesel to } \\
\text { WCO-biodiesel across } \\
\text { different speeds and loads }\end{array}$ \\
\hline
\end{tabular}



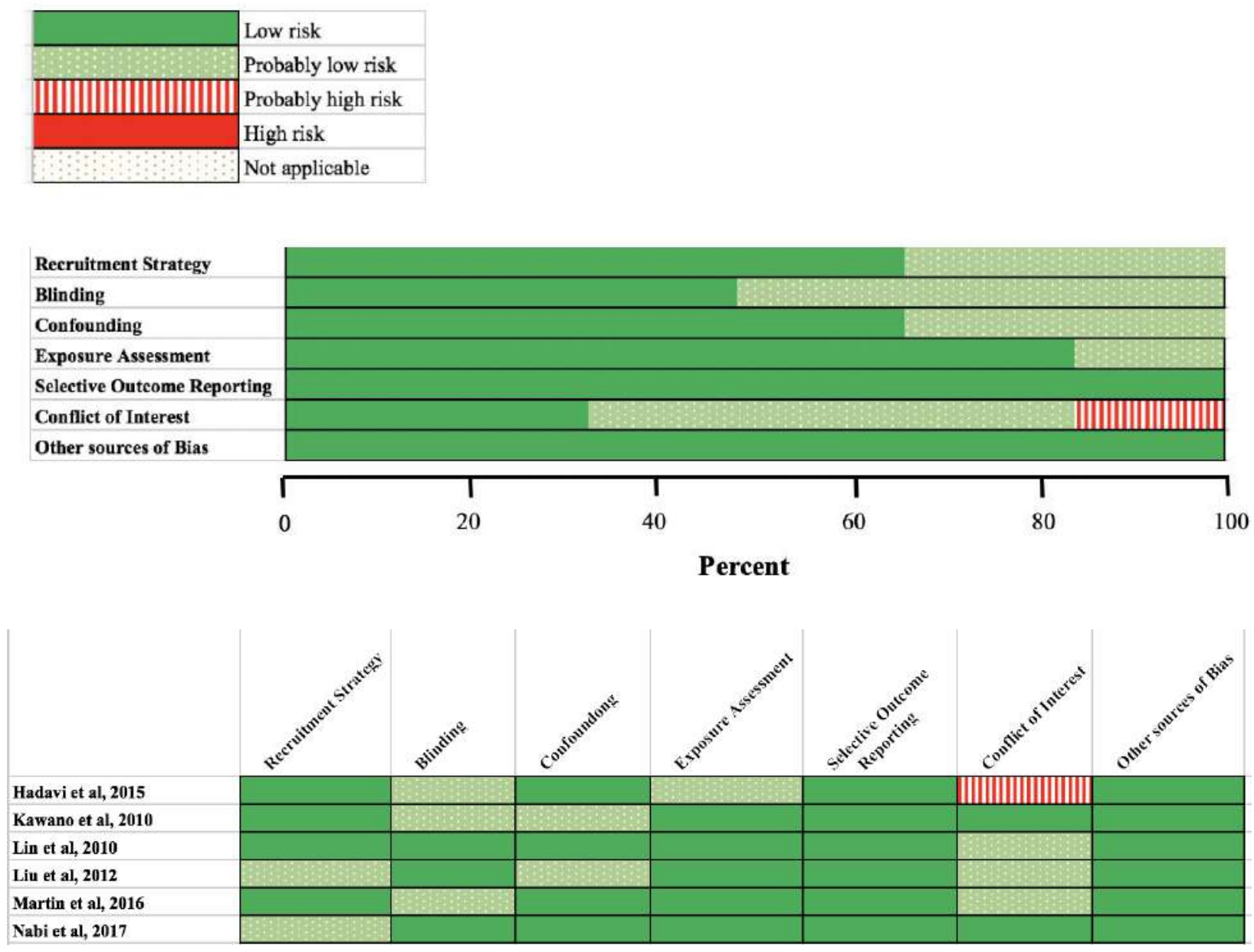

Figure 2b. Risk of bias designations given as percentages across all included studies

\section{Quality and Strength of the Body of Evidence}

After thorough evaluation of the risk of bias within and between the studies chosen, the overall quality of evidence presented was deemed to be of high quality. The only bias domain classified as 'probably high' was the potential conflict of interest for the Hadavi et al study (Hadavi et, as the trucks used in the investigation were provided by a large private multinational food manufacturer. However, it was not warranted as enough to consider the downgrading of the overall study quality.

- The overall strength of evidence was determined based on three considerations.

- The quality of the body of evidence was high

- Direction of the effect estimate: in general, the use of WCO-biodiesel decreased the emissions of PM

- There were no other compelling attributes of the data that influenced uncertainty of the study, and no evidence of publication bias. 
Based on these factors shown, the overall strength of evidence was determined as 'sufficient'. It is believed with reasonable confidence, that the available evidence demonstrates studies that have been well conducted, and results that have been outline concisely.

\section{Discussion}

After concise application of the Navigation Guide tool, it was determined that the major conclusion from the data collected supports the initial hypothesis and demonstrates that the use of waste cooking oil as a biodiesel is a beneficial substitution to standard petroleum diesel when aiming to reduce PM emission concentrations. All six studies chosen for review conducted an experimental intervention by using a $20 \%$ waste cooking oil biodiesel blend on a 6-cylinder heavy-duty engine. The calculated average percentage reduction of particulate matter emissions among the six studies when switching from petroleum diesel to a WCO-biodiesel was $27.9 \%$. This data presented was deemed to be sufficient, with 'high' strength and quality of the evidence presented, as well as a low risk of bias amongst the studies.

Diesel engines are one of the largest sources of particulate emissions, contributing to adverse effects seen in the environment and to human health (Agarwal et al 2015). Diesel particulate matter exposure is thought to be associated with an array of chronic and acute cardiopulmonary health risks, including lung and cardiovascular inflammation, exacerbation of asthma, and development of lung cancer (Martin et al 2016). A study by Pope et al, even suggests than there may be no safe exposure threshold between PM exposure and the development of negative health impacts (Pope et al 2009). These are just some of the public health implications involved with mass utilization of petroleum diesel. A study by the World Bank found that from 1990 to 2013, annual premature deaths attributed to PM emission exposure increased by approximately $30 \%$ from 2.2 to 2.9 million. (World Bank Group 2016).

In addition to reduced PM and other gaseous compound emissions (particularly carbon dioxide and carbon monoxide), the concept of using WCO biodiesel as an alternative fuel source is an attractive one for several reasons. Heavy-duty diesel engines were chosen as the experimental population for this review, as the majority of diesel-powered vehicles in the United States are classified as large trucks, buses, commercial and off-road. The potential scope of influence for switching to a cleaner burning fuel source is a major consideration for implementation of this biodiesel. Additionally, improvements in waste control in conjunction with the increased longevity of the world's rapidly depleting petroleum sources cannot be ignored.

A limitation of this review is that the Navigation Guide utilized for completion, is not really suited to studies that do not have a human population. This made it quite difficult to adjust the risk of bias domains, and strength of evidence categories to adequately assess these papers. Additionally, only two of the six studies evaluated for PM emissions specifically. The rest of the studies encompassed PM into a single particulate matter category, failing to mention the diameter range in which they were specifically measuring for. Although PM would be included in these concentrations, it does not allow from completely synchronous comparisons. Issues for systematic comparisons also arose when looking at different studies, due to the different units used for analyzing and reporting PM emissions between studies. Percentage change in emissions were calculated for each study, to aid in strengthening overall conclusions of the review.

Ample studies have been conducted that demonstrate the improvements in particulate matter and other gaseous pollutant emissions with the use of a WCO biodiesel blend. Feasibility and life-cycle assessments should be further conducted to cover gaps in knowledge and to aid in determining whether mass production, distribution and collection of this form of biodiesel can be transitioned to over the discernable future. Based on the results from this review, it is suggested that enough evidence is present in the literature to warrant the benefits of using waste cooking oil biodiesel blend. 


\section{Conclusion}

Based on the entire evaluation of this evidence using the Navigation Guide, the conclusion of this systematic review is that there is 'sufficient' evidence to suggest an association between reduced PM emissions and the use of WCO-biodiesel in replacement of standard petroleum diesel. As the benefits of reduced PM emissions have been recognized, it is believed that decided action should be taken to determine next steps in regard to mass production and distribution of such a fuel. Waste cooking oil biodiesel is a promising next step towards a more sustainable environment, reduced waste and improved public health.

\section{References}

Agarwal, A. K., Gupta T., Shukla, P.C., Dhar, A. (2015). Particulate Emissions from Biodiesel Fuelled CI Engines. Energy Conversion and Management, 94, 311-330.

Balshem, H., Helfand, M., Schunemann, H. J., Oxman, A. D., Kunz, R., Brozek, J. (2011). Grade Guidelines: 3. Rating the Quality of Evidence. Journal of Clinical Epidemiology, 64, 401- 406.

Hadavi, S., Dizayi, B., Li, H., Tomlin, A. (2015). Emissions from a HGV using Used Cooking Oil as a Fuel under Real World Driving Conditions. Proceedings of the SAE Technical Paper Series, SAE World Congress, Detroit, USA, April, pp. 1-11.

Johnson, P. I., Sutton, P., Atchley, D. S., Koustas, E., Lam, J., Sen, S. (2014). The Navigation Guide - evidencebased medicine meets environmental health: systematic review of human evidence for PFOA effects on fetal growth. Environmental Health Perspectives, 122,1028-1039.

Kawano, D., Mizushima, N., Ishii, H., Goto, Y., Iwasa, K. (2010). Exhaust Emission Characteristics of Commercial Vehicles Fuelled with Biodiesel. SAE International 2010-01-2276.

Lin, Y., Hsu, K., Chen, C. (2010). Experimental Investigation of the Performance and Emissions of a HeavyDuty Diesel Engine Fueled with Waste Cooking Oil Biodiesel/Ultra-low Sulfur Diesel Blends. Energy, 36, 241248.

Liu, S., Lin, Y., Hsu, K. (2012). Emissions of Regulated Pollutants and PAHs from Waste-Cooking-Oil Biodiesel Fuelled Heavy-duty Diesel Engine with Catalyzer. Aerosol and Air Quality Research, 12, $218-227$.

Martin, N., Lombard, M., Jensen, K., Kelley, P., Pratt, T., Traviss, N. (2016). Effect of Biodiesel Fuel on 'Realworld', Nonroad Heavy Duty Diesel Engine Particulate Matter Emissions, Composition and Cytotoxicity. Science of the Total Environment, 586, 409-418.

Nabi, N., Zare, A., Hossain, F., Ristovski, Z., Brown, R. (2017). Reductions in Diesel Emissions including PM and PN Emissions with Diesel-Biodiesel Blends. Journal of Cleaner Production, 166, 860-868.

Pope, C., Ezzati, M., Dockery, D. (2009). Fine-Particulate Air Pollution and Life Expectancy in the United States. The New England Journal of Medicine, 360, 376-386.

Reşitoğlu, I., Altinişik, K., Keskin, A. (2014). The Pollutant Emissions from Diesel-Engine Vehicles and Exhaust Aftertreatment Systems. Clean Technologies and Environmental Policy, 17, 15-27.

U.S. EIA (Energy Information Administration), U.S. Energy Facts Explained. Date of access: 31/10/2017. https://www.eia.gov/energyexplained/?page=us_energy_home.

U.S. EIA (Energy Information Administration), Learn About Biodiesel. Date of access: 31/10/2017. https://www3.epa.gov/region9/waste/biodiesel/questions.html.

U.S. EIA (Energy Information Administration), Petroleum Consumption: Transportation and Electric Power Sectors. Date of access: 31/10/2017. https://www.eia.gov/totalenergy/data/monthly/index.php\#petroleum.

U.S. EIA (Energy Information Administration), Diesel Fuel Explained. Date of access: 31/10/2017. https://www.eia.gov/energyexplained/index.cfm?page=diesel_use.

U.S. Environmental Protection Agency. (2002). Health Assessment Document for Diesel Engine Exhaust. National Center for Environmental Assessment

U.S. EPA (Environmental Protection Agency), Air Quality Communication Workshop. Date of access: 31/10/2017. https://www.epa.gov/sites/production/files/2014-05/documents/huff-particle.pdf.

World Bank Group. (2016). The Cost of Air Pollution: Strengthening the Economic Case for Action. Institute for Health Metrics and Evaluation Dot- EPA/600/8-90/057F 
Omobolanle H. Oshinusi and George M. Gray / Evaluation of PM Emissions of a Diesel Engine....

\section{Appendix}

Risk of Bias Judgements for Individual Studies

Table 1a: Emissions from a HGV using Used Cooking Oil as a Fuel under Real World Driving Conditions. Hadavi et al. 2015

\begin{tabular}{|c|c|c|}
\hline Bias & Rating & Support For Judgement \\
\hline Recruitment Strategy & Low Risk & $\begin{array}{l}\text { All vehicles selected used the same type of } \\
\text { engine as they were from the same fleet }\end{array}$ \\
\hline Blinding & Probably Low Risk & $\begin{array}{c}\text { Was not mentioned although did not seem to } \\
\text { affect study results }\end{array}$ \\
\hline Exposure Assessment & Probably Low Risk & $\begin{array}{l}\text { Consistent alterations were made across all test } \\
\text { vehicles to be able to burn the C2G Ultra } \\
\text { Biofuel }\end{array}$ \\
\hline Confounding & Low Risk & $\begin{array}{l}\text { Not necessarily mentioned, but used the same } \\
\text { drivers and routes for testing }\end{array}$ \\
\hline Selective Outcome Reporting & Low Risk & $\begin{array}{l}\text { All outcomes identified were reported } \\
\text { appropriately }\end{array}$ \\
\hline Conflict of Interest & Probably High Risk & $\begin{array}{l}\text { Although the study was supported in part by } \\
\text { the UK Department of Transport, the trucks } \\
\text { were provided by the United Biscuits Ltd, a } \\
\text { large private multinational food manufacturing } \\
\text { company }\end{array}$ \\
\hline Other bias & Low Risk & No other biases identified \\
\hline
\end{tabular}

Table Ib: Exhaust Emission Characteristics of Commercial Vehicles Fuelled with Biodiesel. Kawano et al, 2010

\begin{tabular}{|c|c|c|}
\hline Bias & Rating & Support For Judgement \\
\hline Recruitment Strategy & Low Risk & $\begin{array}{l}\text { All vehicles used already equipped for WCO- } \\
\text { biodiesel use }\end{array}$ \\
\hline Blinding & Probably Low Risk & $\begin{array}{l}\text { Not acknowledged but may have been effective as } \\
\text { researchers already accustomed to WCO-biodiesel use }\end{array}$ \\
\hline Exposure Assessment & Low Risk & $\begin{array}{l}\text { No alterations made to the engine itself that would } \\
\text { affect PM emissions. Tests completed according to } \\
\text { national regulations. }\end{array}$ \\
\hline Confounding & Probably Low Risk & $\begin{array}{c}\text { Did not mention whether same driving conditions } \\
\text { were utilized, although no evidence to assume } \\
\text { otherwise. }\end{array}$ \\
\hline Selective Outcome Reporting & Low Risk & All outcomes identified were reported appropriately \\
\hline Conflict of Interest & Low Risk & $\begin{array}{c}\text { Study was completed as part of a project for the } \\
\text { Ministry of the Environment of Japan }\end{array}$ \\
\hline Other bias & Low Risk & No other biases identified \\
\hline
\end{tabular}


Table 1c: Experimental Investigation of the Performance and Emissions of a Heavy-duty Diesel Engine Fueled with Waste Cooking Oil Biodiesel/Ultra-low Sulfur Diesel Blends. Lin et al. 2010

\begin{tabular}{|c|c|c|}
\hline Bias & Rating & Support For Judgement \\
\hline Recruitment Strategy & Low Risk & $\begin{array}{l}\text { Testing conducted on engine commonly used for } \\
\text { Federal regulation resting }\end{array}$ \\
\hline Blinding & Low Risk & $\begin{array}{l}\text { Was not mentioned although did not seem to affect } \\
\text { study results }\end{array}$ \\
\hline Exposure Assessment & Low Risk & $\begin{array}{l}\text { No alterations made to the engine itself that would } \\
\text { affect PM emissions. }\end{array}$ \\
\hline Confounding & Low Risk & $\begin{array}{l}\text { Not mentioned, but no evidence to assume results were } \\
\text { affected }\end{array}$ \\
\hline Selective Outcome Reporting & Low Risk & All outcomes identified were reported appropriately \\
\hline Conflict of Interest & Probably Low Risk & $\begin{array}{l}\text { Although study was funded in part by a grant from the } \\
\text { National Science Council of Taiwan, it was also } \\
\text { supported by CPC Corporation, a petroleum, natural gas } \\
\text { and gasoline company }\end{array}$ \\
\hline Other bias & Low Risk & No other biases identified \\
\hline
\end{tabular}

Table Id: Emissions of Regulated Pollutants and PAHs from Waste-Cooking-Oil Biodiesel fuelled Heavy-duty Diesel Engine with Catalyzer. Liu et al. 2012

\begin{tabular}{|c|c|c|}
\hline Bias & Rating & Support For Judgement \\
\hline Recruitment Strategy & Probably Low Risk & Reasons for acquirement of engine were not mentioned \\
\hline Blinding & Low Risk & $\begin{array}{l}\text { Was not mentioned although did not seem to affect study } \\
\text { results }\end{array}$ \\
\hline Exposure Assessment & Low Risk & $\begin{array}{l}\text { No alterations made to the engine itself that would affect } \\
\text { PM emissions. }\end{array}$ \\
\hline Confounding & Probably Low Risk & $\begin{array}{l}\text { Not mentioned, but no evidence to assume results were } \\
\text { affected. Use of catalyzer may have skewed results. }\end{array}$ \\
\hline Selective Outcome Reporting & Low Risk & All outcomes identified were reported appropriately \\
\hline Conflict of Interest & Probably Low Risk & $\begin{array}{l}\text { Although study was funded in part by a grant from the } \\
\text { National Science Council of Taiwan, it was also } \\
\text { supported by CPC Corporation, a petroleum, natural gas } \\
\text { and gasoline company }\end{array}$ \\
\hline Other bias & Low Risk & No other biases identified \\
\hline
\end{tabular}


Table 1e: Effect of Biodiesel Fuel on 'Real-World', Nonroad Heavy Duty Diesel Engine Particulate Matter Emissions, Composition and Cytotoxicity. Martin et al, 2016

\begin{tabular}{|c|c|c|}
\hline Bias & Rating & Support For Judgement \\
\hline Recruitment Strategy & Low Risk & $\begin{array}{l}\text { The study did not interfere with the day to day } \\
\text { operations of workers on site. }\end{array}$ \\
\hline Blinding & Probably Low Risk & $\begin{array}{l}\text { Was not mentioned although did not seem to affect study } \\
\text { results }\end{array}$ \\
\hline Exposure Assessment & Low Risk & $\begin{array}{l}\text { No alterations made to the engine itself that would affect } \\
\text { PM emissions. }\end{array}$ \\
\hline Confounding & Low Risk & $\begin{array}{l}\text { Smoking removed as a confounding variable for PM } \\
\text { inhalation }\end{array}$ \\
\hline Selective Outcome Reporting & Low Risk & All outcomes identified were reported appropriately \\
\hline Conflict of Interest & Probably Low Risk & $\begin{array}{l}\text { No statement claiming conflicts of interest were present, } \\
\text { although no evidence to suggest otherwise. }\end{array}$ \\
\hline Other bias & Low Risk & No other biases identified \\
\hline
\end{tabular}

Table 1f: Reductions in Diesel Emissions including PM and PN Emissions with Diesel-Biodiesel Blends. Nabi et al, 2017|

\begin{tabular}{|c|c|c|}
\hline Bias & Rating & Support For Judgement \\
\hline Recruitment Strategy & Probably Low Risk & $\begin{array}{l}\text { Reasons for acquirement of the engine were not } \\
\text { mentioned. }\end{array}$ \\
\hline Blinding & Low Risk & $\begin{array}{l}\text { Was not acknowledged but not assumed to affect study } \\
\text { results. }\end{array}$ \\
\hline Exposure Assessment & Low Risk & $\begin{array}{l}\text { No alterations made to the engine itself during testing. } \\
\text { Tests completed multiple times under emission testing } \\
\text { regulations. }\end{array}$ \\
\hline Confounding & Low risk & $\begin{array}{l}\text { Not mentioned, but no evidence to assume results were } \\
\text { affected. }\end{array}$ \\
\hline Selective Outcome Reporting & Low Risk & All outcomes identified were reported appropriately \\
\hline Conflict of Interest & Low Risk & Study was funded by the Australian Research Council. \\
\hline Other bias & Low Risk & No other biases identified \\
\hline
\end{tabular}

